\title{
Pengembangan Materi Bola Basket Tahap Fundamental Pada Klub Hutama Manggala Basketball Yang Dikemas Dalam E- Modul
}

\author{
Nasrullah Rifki Fatoni, Supriyadi*, Prisca Widiawati \\ Universitas Negeri Malang, Jl. Semarang No. 5 Malang, Jawa Timur, Indonesia \\ *Penulis korespondensi, Surel: supriyadi.fik@um.ac.id
}

Paper received: 2-2-2022; revised: 21-2-2022; accepted: 27-2-2022

\begin{abstract}
This research is motivated by the importance of trainers understanding the aspects that need to be given during training, especially at the Fundamental stage. The purpose of this research is to develop material for the fundamental stage of basketball at the Hutama Manggala Basketball club which is packaged in an E-module. The research method used is Research \& Development (R\&D) from Borg \& Gall. In this study using three methods, namely analysis, validation, and group testing. Data collection is done by using a questionnaire or questionnaire. There are several values from the aspect of suitability, attractiveness, convenience, and usefulness. From the test results, the percentage values obtained are media experts $93.75 \%$ (very valid), basketball experts $82.76 \%$ (very valid), basketball coaching experts $87.14 \%$ (very valid), small group trials $88.03 \%$ (very valid), a large group trial (very valid) and resulted in the Fundamental stage basketball material containing the history of basketball, facilities and infrastructure in basketball, LTAD Basketball, Abcs training, Athletic Movement, Early Childhood Activities, Psychology early childhood, and videos related to motion and basic techniques in basketball. Based on these results, the fundamental stage basketball material packaged in the Emodule is feasible to use.
\end{abstract}

Keywords: fundamental; basketball; e-module

\begin{abstract}
Abstrak
Penelitian ini dilatarbelakangi dengan pentingnya pelatih memahami aspek-aspek yang perlu diberikan pada saat latihan khususnya di tahap Fundamental. Tujuan dari penelitian ini adalah untuk mengembangkan materi bola basket tahap fundamental pada klub Hutama Manggala Basketballyang dikemas dalam E-modul. Metode Penelitian yang digunakan yaitu Research \& Development (R\&D) dari Borg \& Gall. Dalam penelitian ini menggunakan tiga metode yaitu analisis, validasi serta uji coba kelompok. Pengambilan data dilakukan dengan menggunakan angket ataupun kuesioner. Terdapat beberapa nilai dari aspek kesesuaian, kemenarikan, kemudahan dan kebermanfaatan. Dari hasil pengujian diperoleh nilai persentase yaitu ahli media $93,75 \%$ (sangat valid), ahli bola basket $82,76 \%$ (sangat valid), ahli kepelatihan bola basket $87,14 \%$ (sangat valid), uji coba kelompok kecil 88,03\%(sangat valid), uji coba kelompok besar (sangat valid) dan dihasilkan materi bola basket tahap Fundamental yang berisi Sejarah bola basket, Sarana dan prasaran pada olahraga bola basket, LTAD Basketball, Abcs training, Athletic Movement, Aktivitas Anak Usia dini, Psikologi anak usia dini, dan video terkait gerak dan teknik dasar pada bola basket. Berdasarkan hasil tersebut maka materi bola basket tahap fundamental yang dikemas dalam E-modul layak untuk digunakan.
\end{abstract}

Kata kunci: fundamental; bolabasket; e-modul 


\section{Pendahuluan}

Bola basket merupakan salah satu olahraga yang banyak digemari orang di seluruh dunia (Olympics. S. I, 2020). Dikarenakan bola basket merupakan suatu olahraga yang memiliki atmosfer pertandingan yang tinggi. Di dalam permainan bola basket dipenuhi oleh benturan, kualitas permainan, teknik dan adu mental yang semua aspek tersebut diakumulasikan dengan angka yang dimana setiap tim dapat memperoleh angka tersebut dengan mencetak bola ke dalam ring. Menurut (FIBA-International Basketball Federation, 2020) bola basket merupakan olahraga yang dimainkan oleh 2 tim terdiri dari 5 orang pemain pada setiap timnya. Tujuan tim yakni berusaha agar bisa mencetak poin sebanyak mungkin dengan memasukkan bola ke dalam ring dan mencegah tim lawan untuk mengumpulkan poin. Bola basket sendiri sangatlah populer hal ini dapat dilihat dengan banyaknya kompetisi bola basket yang digulirkan baik di tingkat SD, SMP, SMA, maupun tingkat Mahasiswa.

Khususnya di Indonesia olahraga bola basket merupakan olahraga yang paling digemari sesudah sepak bola hampir semua kalangan mulai dari anak-anak sampai dewasa pun masih sering melakukan maupun mengikuti olahraga ini. Basket sendiri sudah sangatlah berkembang di Indonesia yang dulu hanya suatu olahraga yang tidak begitu digemari oleh masyarakat tetapi sekarang olahraga ini sudah mulai berkembang seperti yang dikatakan (Wibowo \& Hidayatullah, 2017) bahwa di Indonesia sendiri perkembangan bola basket sangantlah pesat terutama dalam segi pembinaan yang dimana sekarang pembinaan mulai diatur dari segi per organisasian yang itu sudah menjadi syarat wajib terbentuk nya pembinaan bola basket, karena olahraga bola basket tidak hanya dilakukan semata-mata untuk olahraga tetapi olahraga ini juga sudah menjadi suatu industri yang menggiurkan. Oleh karena itu di Indonesia olahraga bola basket sudah mulai berkembang pesat, banyak pelatihan-pelatihan bola basket dan tournament-tournament mulai diadakan yang disitu mempunyai tujuan agar olahraga bola basket dapat maju dan berkembang di Indonesia.

Dengan kemajuan bola basket yang sangat pesat perlulah suatu pedoman yang bisa menjadi acuan untuk memberikan suatu pelatihan yang tepat sesuai dengan tahapan seperti LTAD. (Balyi, I., Way, R., \& Higgs, 2016) LTAD atau bisa diartikan sebagai model pengembangan jangka panjang bagi atlet yang telah disusun secara sistematis untuk mengembangkan keunggulan olahraga dan meningkatkan partisipasi aktif dalam organisasi olahraga lokal, regional dan Nasional. Untuk itu perlunya suatu pedoman yang di dalamnya telah mengatur sistem olahraga juga dijelaskan (Pelajaran et al., 2021) agar nantinya ada suatu pedoman tertulis yang dapat dijadikan acuan. khususnya di bola basket sesuai dengan tahapan agar dapat dijadikan suatu acuan dalam memberikan program latihan yang tepat. di Indonesia sendiri khususnya di olahraga bola basket masih belum ada suatu pedoman yang dapat mengatur terkait program jangka panjang mulai dari tahap awal sampai pada tahap akhir.

Penelitian ini dilatarbelakangi pada Pentingnya melatih aspek-aspek tertentu sesuai dengan tahapan nya akan membantu atlet dapat berkembang sesuai dengan tahapan usianya (Balyi, 2016). Dalam hal ini masih banyak klub maupun pelatih yang belum cukup memperhatikan terkait hal-hal yang mendasar khususnya pada tahap fundamental padahal tahap ini merupakan suatu pondasi awal terbentuknya atlet yang berkualitas. Oleh karena itu pelatih dituntut untuk dapat memahami apa saja aspek yang perlu diperhatikan pada saat latihan. Seperti pentingnya mengetahui pelatihan yang tepat sesuai dengan tahapan Fundamental, dan mengenali aktivitas anak usia dini serta mengenali psikologi anak usia dini. Dijelaskan (Sayfei, 2020) arti tahap Fundamental itu iyalah tahapan yang mengatur kegiatan 
anak usia 6-9 tahun yang spesifiksnya yakni (laki-laki 6-9 tahun, Perempuan (6-8 Tahun). Dalam Penelitian (Sukamti, E, 2017) juga Dijelaskan Bahwa Perkembangan motorik anak usia dini sama pentingnya dengan aspek perkembangan yang lain seperti halnya kognitif dan psikologis. Apabila anak tidak dapat melakukan gerakan fisik dengan baik nantinya akan berdampak pada rasa kurang percaya diri dan konsep diri negatif dalam melakukan gerakan fisik yang akan berpengaruh terhadap prestasi atlet. Tidak hanya itu saja, masih ada aspek yang perlu diperhatikan seperti yang dikatakan (Ramadhan, 2019) Pentingnya pelatih mengetahui psikologis atlet agar pelatih dapat melihat tingkat emosi dalam suatu pengajaran atau pelatihan yang nanti aktivitas tersebut dapat mencapai tujuan pengajaran. Tidak hanya itu saja pentingnya pelatih memahami psikologi atletnya juga dijelaskan (Dongoran et al., 2020) pentingnya Pelatih memahami psikologis untuk dapat membuat suatu metode pelatihan yang dapat membangun tingkat kepercayaan diri, pembangunan mental, kan kesiapan tim yang matang. Dikatakan oleh (Apriansyah et al., 2017) bahwa tingkat kapercayaan diri dapat menunjang prestasi atlet dengan penerapan latihan yang telah diperoleh. Dan juga pembentukan mental dalam latihan dijelaskan (Gustian, 2016) pembentukan mentalatlet dalamlatihan akan dapat membantu dalam penerapan teknik maupun fisik pada saat latihan. Pembentukan mental mulai dari anak usia dini juga dijelaskan (Anisah, 2017) pembentukan mental dan karakter mulai dari usai dini akan membantu anak dalam perkembangan sosial lingkunganya. Untuk itu perlunya suatu media yang menjelaskan terkait aspek-aspek dalam pelatihan pada tahap fundamental yang nantinya media tersebut dapat digunakan sebagai referensi oleh klub maupun pelatih.

Berdasarkan permasalahan yang ada di kelompok 6-9 tahun di klub Hutama Manggala Basketball dengan melakukan wawancara terhadap pelatih klub Hutama Manggala Basketball bahwa pelatih kurang memperhatikan terkait program latihan yang dibuat, dan berdasarkan angket yang disebarkan pada 10 pelatih yang ada di klub Hutama Manggala diperoleh hasil yaitu a) Sebanyak $100 \%$ bahwa belum ada modul olahraga yang menunjang praktik dan teori dalam club Hutama Manggala Basketball, b) Sebanyak 85\% menjawab bahwa modul sangat c,ocok digunakan untuk bahan diskusi antara pelatih dan wali murid, c) Sebanyak $92.5 \%$ menjawab bahwa pelatih butuh adanya modul olahraga bola basket untuk dapat menambah pengetahuan terkait perlakuan terhadap anak usia dini dan d) Sebanyak $55 \%$ menjawab bahwa pelatih jarang dan tidak pernah membaca modul sebelumnya.

Tujuan dari penelitian itu yaitu untuk dapat membuat suatu media pembelajaran yang di dalamnya berisi materi terkait aspek-aspek yang perlu diperhatikan oleh pelatih dalam latihan yang tepat untuk anak usia dini. Nantinya isi/materi yang ada di dalam media ini dapat dijadikan referensi pelatih dalam membuat suatu program latihan yang tepat sesuai dengan tahap fundamental, dapat dijadikan sarana diskusi antara pelatih dan wali murid dalam memberikan perlakuan yang tepat sesuai dengan usianya dan juga dapat merangsang literasi pelatih dan wali murid. Sesuai juga dengan tujuan media pembelajaran yaitu untuk suatu perubahan yang positif dalam proses pembelajaran, hal ini sesuai dengan pendapat (Mahnun, 2016) bahwa media pembelajaran merupakan kebutuhan dalam menunjang suksesnya program belajar untuk mencapai suatu perubahan menjadi lebih baik.

Diharapkan nantinya materi terkait bola basket tahap Fundamental ini dapat dijadikan referensi oleh klub dan pelatih dalam membuat suatu sistem latihan yang baik sehingga nantinya atlet dapat berkembang sesuai usianya dan dapat merangsang pelatih dalam meningkatkan literasi terkait olahraga bola basket. E-modul ini nantinya berisi materi yang 
merujuk pada LTAD Basketball yang dimana disitu dijelaskan terkait tahapan pelatihan yang cocok untuk diberikan pada tahap Fundamental. Tidak hanya itu saja materi terkait aktivitas fisik untuk anak usia dini dan psikologi anak usia dini. Dalam E-modul juga terdapat video terkait gerak dan teknik dasar yang diperlukan pada olahraga bola basket. E-modul ini dapat digunakan pada smartphone android dan IOS yang dikemas dengan tampilan yang lebih menarik, mudah dalam penggunaan, ramah lingkungan, dan tidak memakan biaya yang banyak.

\section{Metode}

Penelitian ini menggunakan model penelitian Research \& Development (R\&D) dari (Gall, 2016) yang memiliki 10 langkah untuk penelitian. Peneliti melakukan tiga tahap untuk melakukan penelitian yaitu analisis, validasi serta uji coba kelompok. Penelitian ini dilakukan di klub Hutama Manggala Basketball. Subjek uji coba dalam penelitian ini adalah Pelatih Klub Hutama Manggala Basketball dan pelatih klub bola basket di kota Malang. Adapun pembagiannya yaitu uji coba kelompok kecil sebanyak 7 responden, uji coba kelompok besar sebesar 15 responden. Tahap pertama analisis. Kegiatan yang dilakukan dalam tahap analisis yaitu (1) analisis awal untuk mengetahui masalah yang dihadapi dalam proses pembelajaran maupun praktik yang digunakan untuk mengembangkan e-modul (2) analisis materi yang dilakukan untuk mengidetifikasi, merinci serta menyusun secara runtut terkait materi yang akan diberikan. Tahap kedua adalah validasi. Kegiatan yang dilakukan pada tahap ini adalah (1) pemilihan media yang berkenaan dengan penentuan media yang tepat untuk penyajian materi yang akan digunakan pelajar (2) validasi e-modul yang meliputi uji validasi ahli media, ahli bola basket serta ahli kepelatihan bola basket. Tahap ketiga uji coba kelompok yang mana tahap ini uji coba e-modul yang meliputi uji coba kelompok kecil dan uji coba kelompok besar yang mana hasil uji coba tersebut digunakan untuk menyempurnakan produk e-modul.

Pengumpulan data dilakukan dengan beberapa metode, yaitu metode observasi yang dilakukan dengan pengamatan, jenis pengamatan yang dilakukan adalah partisipatif. Metode angket atau kuesioner yang dilakukan untuk mengetahui masalah awal dan mengukur kualitas produk aplikasi. Data yang diperoleh dari instrumen angket bersifat kuantitatif dan kualitatif. Responden menentukan tingkat persetujuan terhadap suatu peryataan dengan memilih salah satu pilihan yang tersedia. Rumus untuk mengolah data berupa deskriptif persentase yaitu:

Keterangan:

$$
V=\frac{T S E V}{S-\max } \times 100 \%
$$

V : validitas

TSEV : Total skor empirik validator

S-max : Total maksimal yang diharapkan

\section{Hasil dan Pembahasan}

Hasil penelitian ini diperoleh dari berbagai revisi dari beberapa ahli seperti ahli media, ahli bola basket dan ahli kepelatihan bola basket. Dari ahli media revisi lebih pada bentuk Emodul mulai dari tata letak tombol Button pada E-modul, terkait kemenarikan E-modul mulai dari tema, warna dan font tulisan, terakhir pada kelancaran penggunaan E-modul. Sedangkan dari Ahli bola basket lebih pada revisi terkait materi yang akan disajikan seperti penambahan materi terkait Abcs Training dan Athletic Movement, dan yang terakhir dari Ahli kepelatihan 
bola basket lebih pada konten yang dibuat mulai dari kelayakan materi dan video terkait gerak dan teknik dasar yang disajikan.

Tabel 1. Hasil Validasi Ahli Media

\begin{tabular}{llll}
\hline No & Sub Variabel & Skor persentase & Keterangan \\
\hline 1 & Kesesuaian & $95,83 \%$ & Sangat Valid \\
2 & Kemenarikan & $91,66 \%$ & Sangat Valid \\
3 & Kemudahan & $93,75 \%$ & Sangat Valid \\
\hline & Total & $93,75 \%$ & Sangat Valid \\
\hline
\end{tabular}

Tabel 2. Hasil Validasi Ahli Bola Basket

\begin{tabular}{llll}
\hline No & Sub Variabel & Skor persentase & Keterangan \\
\hline 1 & Kesesuaian & $78,57 \%$ & Sangat Valid \\
2 & Kemenarikan & $75 \%$ & Cukup Valid \\
3 & Kemudahan & $87,5 \%$ & Sangat Valid \\
4 & Kebermanfaatan & $90 \%$ & Sangat Valid \\
\hline & Total & $82,76 \%$ & Sangat Valid \\
\hline
\end{tabular}

Tabel 3. Hasil Validasi Ahli Kepelatihan Bola Basket

\begin{tabular}{llll}
\hline No & Sub Variabel & Skor persentase & Keterangan \\
\hline 1 & Kesesuaian & $78,57 \%$ & Sangat Valid \\
2 & Kemenarikan & $87,5 \%$ & Sangat Valid \\
3 & Kemudahan & $87,5 \%$ & Sangat Valid \\
4 & Kebermanfaatan & $95 \%$ & Sangat Valid \\
\hline \multicolumn{5}{c}{ Total } & $87,14 \%$ & Sangat Valid \\
\hline
\end{tabular}

Penilaian yang dilakukan untuk menentukan hasil validasi produk untuk dapat diujicobakan dengan melalui 3 tahap validasi yakni validasi uji media, uji ahli bola basket dan uji ahli kepelatihan bola basket. Hasil yang diperoleh yakni ahli media didapatkan skor ratarata persentase kelayakan sebesar 93,75\%. Nilai tersebut termasuk sangat valid, artinya aplikasi sangat layak untuk digunakan. Ahli bola basket didapatkan skor rata-rata persentase kelayakan sebesar $82,76 \%$. Nilai tersebut termasuk sangat valid, artinya aplikasi sangat layak untuk digunakan. Dan yang terakhir yakni Ahli kepelatihan Bola basket didapatkan skor ratarata persentase kelayakan sebesar 93,75\%. Nilai tersebut termasuk sangat valid, artinya aplikasi sangat layak untuk digunakan. Dari hasil tersebut dapat disimpulkan bahwa produk Emodul dapat untuk diujicobakan.

Berdasarkan hasil Penilaian kelayakan aplikasi yang diberikan pada uji kelompok kecil didapatkan skor rata-rata persentase kelayakan sebesar 88,03\%. Nilai tersebut termasuk cukup valid, artinya aplikasi layak digunakan dengan revisi. Sedangkan penilaian yang diberikan pada uji kelompok besar didapatkan skor rata-rata persentase kelayakan sebesar 92,05\%. Nilai tersebut termasuk sangat valid, dari hasil ke 5 tahapanmulai dari Validasi 3 ahli dan 2 kali uji coba lapangan menurut (Akbar, 2018) artinya aplikasi ini sangat layak untuk digunakan. Adapun link untuk mengakses E-modul Bola Basket pada tahap Fundamental https://drive.google.com/drive/folders/1HfsTloujBePglVEdjJUQSeAEqj0ax6GG?usp=sharing. 
Sport Science and Health, 4(2), 2022, 103-111

Tabel 5. Hasil Penilaian Kelayakan Aplikasi Uji Kelompok Kecil dan Uji Kelompok Besar

\begin{tabular}{|c|c|c|c|c|c|c|c|c|c|}
\hline \multirow{2}{*}{\multicolumn{2}{|c|}{ No Variabel }} & \multicolumn{4}{|c|}{ Kelompok Kecil } & \multicolumn{4}{|c|}{ Kelompok Besar } \\
\hline & & \multirow{2}{*}{$\begin{array}{l}\text { Ts } \\
\mathrm{e} \\
14 \\
7\end{array}$} & \multirow{2}{*}{$\begin{array}{l}\text { TS } \\
h \\
16 \\
8\end{array}$} & \multirow{2}{*}{$\begin{array}{l}\mathrm{V} \\
(\%) \\
87, \\
5\end{array}$} & \multirow{2}{*}{$\begin{array}{l}\begin{array}{l}\text { Keteranga } \\
\mathrm{n}\end{array} \\
\text { Sangat } \\
\text { Valid }\end{array}$} & \multirow{2}{*}{$\begin{array}{l}\text { Tse } \\
333\end{array}$} & \multirow{2}{*}{$\begin{array}{l}\text { TSh } \\
360\end{array}$} & \multirow{2}{*}{$\begin{array}{l}\mathrm{V} \\
(\%) \\
92, \\
5\end{array}$} & \multirow{2}{*}{$\begin{array}{l}\text { Keteranga } \\
\mathrm{n}\end{array}$} \\
\hline 1 & Kesesuaian & & & & & & & & \\
\hline 2 & $\begin{array}{l}\text { Kemenarika } \\
\mathrm{n}\end{array}$ & $\begin{array}{l}11 \\
8\end{array}$ & $\begin{array}{l}14 \\
0\end{array}$ & $\begin{array}{l}84, \\
2\end{array}$ & $\begin{array}{l}\text { Sangat } \\
\text { Valid }\end{array}$ & 266 & 300 & $\begin{array}{l}88 \\
6\end{array}$ & $\begin{array}{l}\text { Sangat } \\
\text { Valid }\end{array}$ \\
\hline 3 & Kemudahan & $\begin{array}{l}14 \\
7\end{array}$ & $\begin{array}{l}16 \\
8\end{array}$ & $\begin{array}{l}87 \\
5\end{array}$ & $\begin{array}{l}\text { Sangat } \\
\text { Valid }\end{array}$ & 326 & 360 & $\begin{array}{l}90, \\
5\end{array}$ & $\begin{array}{l}\text { Sangat } \\
\text { Valid }\end{array}$ \\
\hline 4 & $\begin{array}{l}\text { Kemanfaata } \\
\mathrm{n}\end{array}$ & 78 & 84 & $\begin{array}{l}92, \\
8\end{array}$ & $\begin{array}{l}\text { Sangat } \\
\text { Valid }\end{array}$ & 174 & 180 & $\begin{array}{l}96, \\
6\end{array}$ & $\begin{array}{l}\text { Sangat } \\
\text { Valid }\end{array}$ \\
\hline \multicolumn{2}{|c|}{ Jumlah } & $\begin{array}{l}49 \\
0 \\
\end{array}$ & $\begin{array}{l}56 \\
0 \\
\end{array}$ & $\begin{array}{l}88, \\
3 \\
\end{array}$ & $\begin{array}{l}\text { Sangat } \\
\text { Valid }\end{array}$ & $\begin{array}{l}1.09 \\
9 \\
\end{array}$ & $\begin{array}{l}1.20 \\
0 \\
\end{array}$ & $\begin{array}{l}92, \\
5 \\
\end{array}$ & $\begin{array}{l}\text { Sangat } \\
\text { Valid }\end{array}$ \\
\hline
\end{tabular}

Pentingnya pelatih memahami aspek-aspek khususnya pada tahap fundamental akan sangat berpengaruh terhadap perkembangan atlet tersebut. Dalam tahap fundamental banyak aspek yang perlu diperhatikan mulai dari pelatihan yang tepat pada tahap fundamental, terkait aktivitas anak usia dini dan pentingnya pelatih memahami psikologis anak usia dini. Menurut (Setiawan, 2019) memberikan porsi latihan fisik yang berlebihan pada anak merupakan salah satu faktor yang dapat menyebabkan cedera pada usia lanjutnya. Pentingnya memberikan pelatihan yang tepat pada tahapan nya juga dijelaskan (Myer et al., 2020) pentingnya memberikan suatu pelatihan yang tepat sesuai dengan usianya dapat mengurangi resiko pada cedera olahraga dan dapat meningkatkan kinerja athletic. Memberikan pelatihan sesuai dengan usianya tidak hanya terkait cedera olahraga tetapi juga akan dapat berdampak pada aktivitas dan psikologi anak tersebut. Seperti yang dijelaskan (Takken et al., 2020) memberikan latihan pada anak usia dini dengan memperhatikan gerak dasar, bermain dan melakukan aktivitas yang menarik dapat membantu anak dalam mengembangkan fisik yang optimal dan berpengaruh pada psikososial anak. Dijelaskan juga pentinya peberian latihan yang tepat sesuai dengan usianya juga akan berpengaruh terhadapat stimulasi perkembangan perilaku anak dijelaskan oleh (Arniansyah, 2018) dalam umur 6-10 pentingnya meberikan pelatihan bersosial dalam olahraga juga dapat mepengaruh stimulus perilaku terhadapanak untuk itu penting untuk dberikan sedikit bentuk pembelajran terkait hal-hal seperti ini. Dari hal tersebut dapat dilihat bahwa pentingnya pelatih memberikan pelatihan yang tepat sesuai usianya agar anak dapat berkembang dengan baik.

Dari aspek pentingnya pelatih memperhatikan aktivitas fisik anak usia dini juga dijelaskan oleh (Rohmah, 2016) mengatakan Adapun manfaat memperhatikan aktivitas fisik anak mulai dari aspek motorik dan kognitif nya dapat berpengaruh signifikan terhadap tubuh dan berkembangnya anak. Untuk itu perlunya peran Orang tua atau pun pengajar dalam hal ini pelatih dalam memperhatikan aspek ini yang nantinya anak tidak hanya memiliki bekal terkait olahraga tersebut tetapi anak juga memiliki bekal aspek moral, motorik, kognitif, bahasa, serta perkembangan sosial yang baik yang nanti dapat diterapkan anak pada lingkungannya. Tidak hanya itus aja meperhatikan aktivitas fisik juga dapat berpengaruh terhadap kebugaran jasmani anak seperti yang dikatakan (Erliana \& Hartoto, 2019) bahwa memperhatikan tingkat aktivitas fisik akan berpengaruh terhadap tingkat kebugaran jasmani anak. Pentingnya memperhatikan aktivitas fisik pada anak juga dapat berpengaruh terhadap kesehatan anak jelaskan (Moola et al., 2017) bahwa pentingnya memberikan aktivitas fisik pada anak yang nantinya akan berdampak pada kesehatan anak tersebut. Tidak hanya itu saja memperhatikan 
aktifitas fisik anak akan dapat berpengarh terhadap tumbuh kembang anak seperti yang dikatakan (Burhaein, 2017) dalam periode ini anak sangat gampang dalam pertumbuhanya mulai dari segi pertumbuhan badan maupun pertumbuhan otaknya. Dan juga pentingnya memperhatikan aspek lain seperti psikologi anak juga dijelaskan (Afrianto \& Zulfiati'aini, 2020) memperhatikan psikologi anak dapat berpengaruh pada tingkat stres anak, tingkat kebahagiaan anak dan kesulitan anak dalam pemahaman di lapangan. Tidak hanya itu dijelaskan bahwa pentingnya pelatih memperhatikan aspek psikologi (Poczwardowski et al., 2016) pentingnya pelatih melakukan pendekatan psikologi kepada athlete akan berpengaruh terhadap kinerja athlete dalam antusiasme terhadap situasi di lapangan. Untuk itu E-modul ini akan membantu klub dan pelatih Hutama Manggala Basketball dalam menjadikan referensi untuk membuat program latihan untuk anak usia dini.

Tujuan penelitian ini untuk dapat mengembangkan materi bola basket tahap fundamental pada klub Hutama Manggala Basketball yang dikemas dalam E-modul. . E-modul dapat dijadikan sarana pembelajaran seperti yang dikatakan (TANIA, 2017) dalam pembelajaran saat ini yang dimana perkembangan teknologi mulai pesat media pembelajaran berbasis Elektronik seperti contoh E-modul untuk dapat menunjang pembelajaran sangat lah efisien dikarenakan nanti atlet, orangtua maupun pelatih dapat mengakses media tersebut dengan mudah. Pentinya memberikan media pembelajaran juga dijelaskan (Rohani, 2019) Kaitan pembelajaran merupakan suatu kegiatan yang membutuhkan proses interaksi dan komunikasi yang didalamnya mengandung pesan berupa informasi maupun keterangan diri. Nantinya materi dalam E-modul ini akan dijadikan media diskusi oleh pelatih dan wali murid terkait perlakuan yang tepat terhadap anak usia dini. Dan dijadikan bahan referensi oleh klub dan pelatih untuk dapat membuat program latihan dengan melihat aspek-aspek yang ada di dalam E-modul ini.

Penelitian terkait pengembangan materi bola basket tahap fundamental pada klub Hutama Manggala Basketball yang dikemas dalam E-modul didasari dari tahpan-tahapan penelitan seperti yang dikatakan (Zakariah, M. A., Afriani, V., \& Zakariah, 2020) analisis kebutuhan awal melalui wawancara pelatih klub Hutama Manggala Basketball dan penyebaran angket kepada 10 pelatih klub Hutama Manggala basketball, dalam pembuatan produk juga sudah melalui tahap validasi ahli yang terdiri dari 3 ahli yakni ahli media, ahli bola basket dan ahli kepelatihan bola basket dan dilanjutkan uji coba kelompok kecil dan uji coba kelompok besar kepada pelatih klub yang ada di kota Malang. Rancangan tahapan penelitian diawali dengan pembuatan instrumen analisis kebutuhan, dilanjutkan dengan analisis materi yang dilakukan untuk mengidetifikasi, merinci serta menyusun secara runtut terkait materi yang akan diberikan. Validasi terkait kelayakan E-modul dan revisi terkait teknis aplikasi serta materi yang disajikan agar dapat diujicobakan. Sampai pada tahap akhir dimana aplikasi Emodul sudah melewati tahapan-tahapan terkait kelayakan produk dan produk layak untuk digunakan. Nantinya materi dalam produk ini akan digunakan klub Hutama Manggala Basketball sebagai media referensi klub dan pelatih dalam membuat program latihan pada tahap fundamental dan dijadikan media diskusi antara pelatih dan wali murid. Diharapkan dengan adanya E-modul ini nantinya dapat merangsang literasi bagi Pelatih untuk dapat lebih memahami terkait olahraga bola basket.

Dalam penelitian (Sukamti, E, 2017) Dijelaskan Bahwa pentingnya Perkembangan motorik anak usia dini sama pentingnya dengan aspek perkembangan yang lain seperti halnya kognitif dan psikologis. Apabila anak tidak dapat melakukan gerakan fisik dengan baik 
nantinya akan berdampak pada rasa kurang percaya diri dan konsep diri negatif dalam melakukan gerakan fisik yang akan berpengaruh terhadap prestasi atlet. Gerak fisik juga penting diberikan pada anak usia dini seperti yang dikatakan (Yudanto, 2020) pengaruh gerak dasar pada anak perlu diberikan agar anak tidak kesulitan melakukan gerak tersebut dikemudian hari. Diadopsi dari penelitian sebelumnya bahwa pentingnya pengajar dalam memperhatikan aktivitas fisik anak dan melihat psikologis nya dapat berpengaruh terhadap tingkat kepercayaan diri yang nanti akan mempengaruhi prestasi atlet. keterbaruan dan keunggulan penelitian ini adalah penggabungan terkait teori penelitian sebelumnya dengan olahraga bola basket, adanya bentuk produk berupa E-modul dikemas secara ringkas yang berisi terkait teori yang merujuk pada LTAD Basketball, menjabarkan terkait aktivitas dan psikologi anak usia dini. Produk ini dapat digunakan di smartphone android maupun IOS sehingga dapat digunakan dimana saja, tampilan lebih menarik dan lebih praktis dalam penggunaannya, tidak memakan biaya serta dilengkapi dengan video terkait gerak dan teknik dasar pada olahraga bola basket.

\section{Simpulan}

Berdasarkan hasil penelitian diperoleh kesimpulan yaitu penelitian ini dihasilkan sebuah e-modul olahraga bola basket yang didalamnya terdiri dari text, gambar serta video. Pengembangan Materi bola basket tahap Fundamental yang dikemas dalam E-modul dapat dioperasikan kapan saja menggunakan smartphone yang telah di-instal E-modul olahraga bola basket. Penelitian menghasilkan e-modul olahraga bola basket yang sangat valid atau dapat digunakan.

\section{Daftar Rujukan}

Afrianto, A., \& Zulfiati'aini, S. A. (2020, December). Mengoptimalkan Kesejahteraan Psikologis Anak Melalui Permainan Tradisional Dimasa Pandemi COVID-19. In (Webinar) Seminar Nasional Pendidikan 2020 (Vol. 1, No. 1, pp. 007-012).

Akbar, S. (2018). Model Penelitian dan Pengembangan.

Anisah, A. S. (2017). Pola asuh orang tua dan implikasinya terhadap pembentukan karakter anak. Jurnal Pendidikan UNIGA, 5(1), 70-84.

Apriansyah, B., Sulaiman, S., \& Mukarromah, S. B. (2017). Kontribusi motivasi, kerjasama, kepercayaan diri terhadap prestasi atlet sekolah sepakbola Pati Training Center di Kabupaten Pati. Journal of Physical Education and Sports, 6(2), 101-107.

Arniansyah, A., Nadhilla, N., Permatasari, R. E., Milani, T., \& Putri, Y. W. A. (2018). Pelatihan Empati dan Perilaku Prososial pada Anak Usia 6-12 Tahun di Rptra Anggrek Bintaro. Jurnal Muara Ilmu Sosial, Humaniora, Dan Seni, 2(1), 432-439.

Balyi, I., Way, R., \& Higgs, C. (2016). Long threme athlete development. Human Kinetics.

Balyi, I. (2016). We acknowledge the fi nancial support of the Government of Canada through Sport Canada, a branch of the Department of Canadian Heritage . Long-Term Athlete Development December 2008 ISBN 978-0-9811969-0-9.

Burhaein, E. (2017). Aktivitas Fisik Olahraga untuk Pertumbuhan dan Perkembangan Siswa SD. Indonesian Journal of Primary Education, 1(1), 51. https://doi.org/10.17509/ijpe.v1i1.7497

Dongoran, M. F., Kalalo, C. N., \& Syamsudin. (2020). Profil Psikologis Atlet Pekan Olahraga Nasional (PON) Papua Menuju PON XX Tahun 2020. Journal Sport Area, 5(1), 13-21. https://doi.org/10.25299/sportarea.2020.vol5(1).4621

Erliana, E., \& Hartoto, S. (2019). Hubungan Aktivitas Fisik Terhadap Tingkat Kebugaran Jasmani Siswa. Jurnal Pendidikan Olahraga Dan Kesehatan, 7(2), 225-228.

FIBA-International Basketball Federation. (2020). Rules, Basketball Equipment, Basketball. FIBA-International Basketball Federation, v1.0a, 98. 
Gall, B. (2016). Education Research.

Gustian, U. (2016). Pentingnya Perhatian dan Konsentrasi dalam Menunjang Penampilan Atlet. Sport Science, 1(01), 89-.

Mahnun, N. (2016). Media Pembelajaran (Kajian terhadap Langkah-langkah Pemilihan Media dan Implementasinya dalam Pembelajaran). An-Nida'.

Moola, F., Faulkner, G. E. J., Kirsh, J. A., \& Kilburn, J. (2017). Physical activity and sport participation in youth with congenital heart disease: Perceptions of children and parents. Adapted Physical Activity Quarterly, 25(1), 49-70. https://doi.org/10.1123/apaq.25.1.49

Myer, G. D., Faigenbaum, A. D., Chu, D. A., Falkel, J., Ford, K. R., Best, T. M., \& Hewett, T. E. (2020). Integrative training for children and adolescents: techniques and practices for reducing sports-related injuries and enhancing athletic performance. The Physician and Sportsmedicine, 39(1), 74-84. https://doi.org/10.3810/psm.2011.02.1864

Olympics. S. I. (2020). Buku Panduan Olaharaga Bola Basket. Special Olympics Indonesia.

Pelajaran, P., Jasmani, P., \& Dan, O. (2021). PIOR: Jurnal Pendidikan Olahraga. xxx(xxx), 9-13.

Poczwardowski, A., Barott, J. E., \& Jowett, S. (2016). Diversifying approaches to research on athlete-coach relationships. Psychology of Sport and Exercise, 7(2), 125-142. https://doi.org/10.1016/j.psychsport.2005.08.002

Ramadhan, F. (2019). Pentingnya mengetahui psikologi atlet dalam melakukan pengajaran dan pelatihan. Sport Science.

Rohani, R. (2019). Diktat Media Pembelajaran. Fakultas Ilmu Tarbiyah Dan Keguruan Universitas Islam Negeri Sumatera Utara.

Rohmah, N. (2016). Bermain Dan Pemanfaatannya Dalam Perkembangan Anak Usia Dini. Jurnal Tarbawi, 13(2), 27-35.

Sayfei, M. (2020). Sayfei, Muhamad, et al. "Identifikasi Keberbakatan Menggunakan Metode Australian Sport Search Terhadap Kesesuaian Cabang Olahraga Pada Anak Sekolah Dasar. Sport Science, Physical A.

Setiawan, A. (2019). Faktor Timbulnya Cedera Olahraga. Media Ilmu Keolahragaan Indonesia, 1(1). https://doi.org/10.15294/miki.v1i1.1142

Sukamti, E, R. (2017). Perkembangan Motorik Kasar Anak Usia Dini Sebagai Dasar Menuju Prestasi Olah Raga. Sport Science, Perkembangan Motorik Kasar Anak Usia Dini Sebagai Dasar Menuju Prestasi Olah Raga.

Takken, T., Giardini, A., Reybrouck, T., Gewillig, M., Hövels-Gürich, H. H., Longmuir, P. E., McCrindle, B. W., Paridon, S. M., \& Hager, A. (2020). Recommendations for physical activity, recreation sport, and exercise training in paediatric patients with congenital heart disease: A report from the Exercise, Basic \& Translational Research Section of the European Association of Cardiovascular Preventio. European Journal of Preventive Cardiology, 19(5), 1034-1065. https://doi.org/10.1177/1741826711420000

Tania, L. (2017). Pengembangan Bahan Ajar E-Modul Sebagai Pendukung Pembelajaran Kurikulum 2013 Pada Materi Ayat Jurnal Penyesuaian Perusahaan Jasa Siswa Kelas X Akuntansi Smk Negeri 1 Surabaya. Jurnal Pendidikan Akuntansi (JPAK), 5(2), 1-9.

Wibowo, K., \& Hidayatullah, M. F. (2017). Evaluasi Pembinaan Prestasi Olahraga Bola Basket di Kabupaten Magetan. Media Ilmu Keolahragaan Indonesia, 7(1), 9-15. https://doi.org/10.15294/miki.v7i1.9520

Yudanto, Y. (2020). Pengaruh model aktivitas jasmani berbasis perseptual motorik terhadap gerak dasar manipulatif anak taman kanak-kanak The influence of physical activity model based on perceptual motor skills on kindergarten students ' manipulative fundamental motor. Jurnal SPORTIF: Jurnal Penelitian Pembelajaran, 6(1), 92-104.

Zakariah, M. A., Afriani, V., \& Zakariah, K. M. (2020). Metodologi Penelitian Kualitatif, Kuantitatif, Action Research, Research and Development $(R n D)$. Yayasan Pondok Pesantren Al Mawaddah Warrahmah Kolaka. 